Artikel Penelitian

\title{
OPTIMALISASI PERENCANAAN PERBAIKAN STRATEGIS DENGAN PELAKSANAAN STANDAR AKREDITASI PASCASURVEI
}

\author{
AAM SUMADI ${ }^{1,2,3}$ dan AGUS SUMARNO ${ }^{3}$ \\ ${ }^{1}$ Rumah Sakit Haji Jakarta \\ ${ }^{2}$ Komisi Akreditasi Rumah Sakit \\ ${ }^{3}$ Universitas Islam As-Syafi'iyah \\ Email korespondensi: aam_sumadi@yahoo.com \\ Dikirimkan 11 Februari 2021, Diterima 18 Mei 2021
}

\begin{abstract}
Abstrak
Latar Belakang: Rumah Sakit yang telah mendapatkan status akreditasi nasional diwajibkan membuat Perencanaan Perbaikan Strategis (PPS) sesuai dengan rekomendasi surveyor untuk memenuhi standar pelayanan rumah sakit yang belum tercapai. Rumah Sakit (RS) menyampaikan PPS ke Komisi Akreditasi Rumah Sakit (KARS) satu bulan setelah survei akreditasi. PPS merupakan strategi/pendekatan yang akan diterapkan RS untuk menangani setiap temuan sebagai tindak lanjut dan bukti komitmen langkah-langkah yang akan dilakukan dalam memenuhi standar yang belum dilaksanakan dalam waktu satu tahun. Implementasi PPS dilihat saat survei verifikasi yang bertujuan untuk mengevaluasi RS dalam mempertahankan, dan atau meningkatkan mutu pelayanan RS sesuai dengan rekomendasi dari surveyor.
\end{abstract}

Tujuan: Penelitian ini bertujuan untuk menganalisis hubungan antara variabel independen, yaitu PPS dengan variabel dependen yaitu hasil survei verifikasi akreditasi 1 di RS yang terakreditasi paripurna Standar Nasional Akreditasi Rumah Sakit (SNARS) edisi 1.

Metode: Penelitian ini merupakan kuantitatif observasional dengan menganalisis data retrospektif, bersumber dari big data KARS yaitu dokumentasi RS yang telah dilakukan akreditasi dengan kriteria inklusi yaitu 8 RS yang telah dilakukan survei verifikasi ke 1 dan memiliki PPS. penilaian akreditasi oleh KARS periode 1 Januari 2018 sampai dengan 31 Desember 2019, dengan perhitungan sampel 61 RS.

Hasil: Hasil penilaian survei verifikasi 1 yang terpenuhi 65,50\%, dan belum terpenuhi 37,50\%. Dari 37,50\% yang belum terpenuhi terdapat peningkatan pada semua standar sebesar $16,23 \%$ dari $25,50 \%$ pada saat survei. Variabel PPS yang lengkap $37,50 \%$, dan tidak lengkap $65,50 \%$ dengan sub variabel metode perbaikan yang dibuat oleh RS dengan rerata 91,75 dengan nilai tertinggi, artinya RS memahami strategi yang dilaksanakan dan sub variabel kesesuaian waktu implementasi maksimal 1 bulan setelah survei dengan rerata 45,75 merupakan nilai terendah, artinya RS belum mengimplementasikan metode perbaikan berdasarkan target waktu yang direncanakan.

Kesimpulan: Penelitian ini menunjukkan PPS tidak ada hubungannya dengan hasil survei verifikasi. Disarankan bahwa PPS harus dibuat sesuai dengan standar dan dilaksanakan dengan baik sesuai target waktu yang direncanakan.

Kata kunci: PPS, survei verifikasi, SNARS Edisi 1

\section{Latar Belakang}

Peraturan Menteri Kesehatan (Permenkes) Nomor 12 Tahun 2020 tentang Akreditasi Rumah Sakit menyatakan bahwa rumah sakit yang telah mendapatkan status akreditasi nasional diwajibkan membuat perencanaan perbaikan strategis sesuai dengan rekomendasi surveyor untuk memenuhi standar pelayanan rumah sakit yang belum tercapai ${ }^{1}$. Rumah sakit menyampaikan perencanaan perbaikan strategis (PPS) ke KARS dengan memanfaatkan teknologi informasi dan komunikasi satu bulan setelah survei akreditasi, setelah sertifikat akreditasi diterima rumah sakit ${ }^{2,3}$. PPS merupakan strategi/pendekatan yang akan diterapkan rumah sakit untuk menangani setiap temuan sebagai tindak lanjut dan bukti komitmen langkahlangkah yang akan dilakukan dalam memenuhi standar yang belum dilaksanakan ${ }^{1}$ dalam waktu satu tahun.

PPS berisi penjelasan tindakan spesifik yang akan digunakan untuk mencapai kepatuhan dan penjelasan metodologi untuk mencegah kembalinya tindakan ketidakpatuhan standar. PPS harus menunjukkan bahwa tindakan yang dilakukan rumah sakit untuk dapat mencapai terpenuhi lengkap dari setiap standar dan elemen penilaian ${ }^{2}$. Di rumah sakit X, salah satu kondisi krusial yang harus dihadapi adalah rendahnya 
kepatuhan terhadap prosedur penggunaan dan pelepasan Alat Pelindung Diri (APD). Berbagai alasan melatari rendahnya kepatuhan penggunaan APD sangat tinggi pada perawat yang sudah mengikuti pelatihan sebesar $88.60 \% 4$. Faktor-faktor yang mempengaruhi tingkat kepatuhan dalam hal penerapan asesmen medis oleh Dokter Penanggung Jawab Pelayanan (DPJP) di seluruh ruangan RS. X adalah faktor sumber daya manusia, material, regulasi, dan kepemimpinan 5 .

Berdasarkan Permenkes nomor 34 tahun 2017 tentang akreditasi bahwa survei verifikasi bertujuan untuk mempertahankan dan atau meningkatkan mutu pelayanan RS sesuai dengan rekomendasi dari surveyor ${ }^{6}$. Survei verifikasi sebagai bentuk kegiatan yang dilakukan KARS untuk mengevaluasi implementasi PPS pada tahun pertama dan tahun kedua setelah akreditasi. RS yang telah terakreditasi tersebut akan dilihat kembali implementasi standar-standar yang pada saat survei belum terpenuhi maka saat survei verifikasi diharapkan telah terimplementasi dengan baik dan standar yang telah terimplementasi diharapkan masih tetap terimplementasi secara konsisten.

Studi pendahuluan dengan melakukan wawancara pada tanggal 4 Mei 2020 melalui telepon dengan 7 orang surveyor keperawatan yang saat ini masih aktif bekerja di RS yang melakukan survei verifikasi akreditasi di RS lain, menyatakan bahwa ada beberapa RS yang saat dilakukan survei verifikasi 1 dan ke 2 hasilnya baru sebagian, atau 50,00\% dari rekomendasi surveyor yang telah terimplementasi. Ada RS yang menyatakan PPS baru beberapa bulan dibuat mendekati waktu survei diakibatkan keterlambatan RS menerima laporan hasil survei verifikasi, dan ada RS yang menyatakan tidak mengerti bahwa target waktu yang ditulis di PPS pelaksanaan perbaikan bisa kapan saja bahkan tertulis untuk tahun berikutnya, sehingga PPS dikerjakan mendekati waktu survei verifikasi. Beberapa hal yang mengakibatkan belum seluruhnya terimplementasi dengan baik dikarenakan faktor sarana prasarana yang membutuhkan biaya tidak sedikit, contoh pemenuhan standar Pencegahan Pengendalian Infeksi (PPI), seperti ketersediaan ruang isolasi dengan tekanan negatif dan tempat pencampuran obat intravena/obat suntik yang dalam periode 1 tahun setelah survei belum terimplementasi.

Lembaga independen penyelenggara akreditasi KARS dapat mencabut penetapan status akreditasi RS, apabila hasil survei verifikasinya menyatakan bahwa RS tidak sesuai lagi dengan status akreditasinya, karena tidak dapat mempertahankan atau meningkatkan mutu pelayanan sesuai dengan rekomendasi surveyor ${ }^{6}$. Pendekatan yang harus dilakukan RS untuk memastikan bahwa akreditasi mencapai tujuan yang diinginkan dengan memastikan pelayanan yang berkualitas sesuai prinsip akreditasi dan RS harus bertanggung jawab atas pelayanan sesuai dengan status akreditasinya ${ }^{13}$.

Akreditasi rumah sakit berdampak positif dalam meningkatkan kualitas pelayanan yang diberikan di $\mathrm{RS}^{14,15}$. Akreditasi mengintensifkan kegiatan yang berkontribusi pada peningkatan kualitas pelayanan kesehatan7, meskipun ada penurunan kinerja setelah survei, tetapi kemudian menunjukkan bahwa terjadi peningkatan kembali standar yang telah dicapai dan dipertahankan selama siklus akreditasi tiga tahunan ${ }^{8}$. Perbandingan kualitas pelayanan setelah survei akreditasi dengan periode saat dilakukan akreditasi, didapatkan tren penurunan yang menunjukkan kualitas pelayanan tetap berlanjut, tetapi pada tingkat yang lebih rendah daripada saat dilakukan survei akreditasi ${ }^{16}$.
Setelah akreditasi perlu dilakukan pembinaan dan pengawasan dengan mengikutsertakan pemerintah dan pemerintah daerah, dengan melibatkan organisasi profesi, asosiasi RS dan tokoh masyarakat9. Pembinaan dan pengawasan bertujuan agar RS dapat mempertahankan dan atau meningkatkan mutu pelayanan ${ }^{1}$. Badan pengawas tersebut mengoptimalkan perannya dalam pembinaan dan pengawasan terhadap mutu RS dengan meningkatkan interaksi antara RS, Dinas Kesehatan Provinsi dan KARS.

Penelitian dilakukan untuk mengidentifikasi dan menganalisis hubungan PPS dengan hasil survei verifikasi di RS yang terakreditasi SNARS edisi 1. Penelitian ini berupaya untuk meningkatkan kemampuan RS dalam menyusun PPS dan mengimplementasikan standar yang menjadi rekomendasi dari surveyor setelah dilakukan survei akreditasi.

\section{Metode}

Penelitian menggunakan rancangan kuantitatif observasional restropektif dengan pendekatan cross sectional, bertujuan untuk menganalisis hubungan antara variabel independent, yaitu PPS dengan variabel dependen yaitu hasil survei verifikasi 1 akreditasi di RS yang terakreditasi paripurna SNARS edisi 1. Penelitian dilakukan setelah mendapatkan kaji laik etik dari Komisi Etik Penelitian Fakultas Kedokteran, Kesehatan Masyarakat dan Keperawatan Universitas Gadjah Mada (UGM) dan persetujuan dari KARS.

Sampel dalam penelitian ini diambil secara random sampling yang memenuhi kriteria yaitu 61 RS yang terakreditasi paripurna SNARS edisi 1 periode 1 Januari 2018 sampai 31 Desember $2019^{10}$. Karena keterbatasan data sekunder di KARS, sehingga hanya tersedia data dari 8 RS yang sesuai kriteria inklusi yang telah dilakukan survei verifikasi pertama dan memiliki PPS. Pengumpulan data menggunakan data hasil survei verifikasi dan data PPS yang dikembangkan peneliti dengan item pernyataan observasi.

Analisis data dilakukan secara univariat dan bivariat. Analisis univariat mendeskripsikan distribusi frekuensi, persentase PPS dan persentase hasil survei verifikasi 1. Uji normalitas menggunakan shapiro wilk. menunjukkan data kedua variabel berdistribusi normal (sig >0,05) ${ }^{11}$. Analisis bivariat dilakukan dengan uji chi-square untuk melihat hubungan variable PPS dengan variabel hasil survei menggunakan tingkat kemaknaan $5,00 \%(\mathrm{p} \mathrm{o}, 05)^{12}$.

\section{Hasil}

Tabel 1 menunjukkan persentase PPS yang lengkap 37,50\% dan yang tidak lengkap $62,50 \%$. Pada sub variabel standar elemen penilaian, langkah pemenuhan elemen penilaian, metode perbaikan yang dibuat, indikator pencapaian perbaikan, waktu implementasi maksimal 1 bulan setelah survei, ada penanggung jawab kegiatan, didapatkan nilai tertinggi kesesuaian pada sub variabel metode perbaikan yang dibuat dengan rerata 91,75.

Tabel 1. Distribusi frekuensi perencanaan perbaikan strategis RS terakreditasi paripurna SNARS edisi 1 periode 1 Januari 2018-31 Desember $2019(\mathrm{n}=8)$

\begin{tabular}{lcc}
\hline Kategori & Frekuensi & Persen (\%) \\
\hline Tidak lengkap & 5 & 62,50 \\
Lengkap & 3 & 37,50 \\
Total & 8 & 100,00 \\
\hline
\end{tabular}


Kesesuaian waktu implementasi maksimal 1 bulan setelah survei dengan rerata 45,75 (tabel 2). Hasil analisis ini menunjukkan pemahaman RS dalam pembuatan metode perbaikan sudah sangat baik, sedangkan target waktu perencanaan implementasi belum semua dituliskan dalam PPS, artinya rumah sakit belum mengimplementasikan metode perbaikan berdasarkan target waktu yang direncanakan.

Tabel 2. Sub variabel perencanaan perbaikan strategis RS terakreditasi paripurna SNARS edisi 1 periode 1 Januari 2018-31 Desember 2019 $(\mathrm{n}=8)$

\begin{tabular}{lcc}
\hline Sub Variabel PPS & Mean & Std. deviation \\
\hline Sub elemen penilaian & 91,63 & 23,68 \\
Langkah pemenuhan elemen penilaian & 87,50 & 24,86 \\
Metode perbaikan yang dibuat & 91,75 & 15,27 \\
Indikator pencapaian perbaikan & 75,13 & 23,58 \\
Waktu implementasi maksimal 1 bulan & 45,75 & 17,59 \\
Ada penanggung jawab kegiatan & 79,25 & 24,82 \\
\hline
\end{tabular}

Tabel 3 dan 4 menunjukkan hasil penilaian survei verifikasi 1 yang terpenuhi $65,50 \%$ dan yang belum terpenuhi $37,50 \%$. Dari $37,50 \%$ yang belum terpenuhi terdapat peningkatan pada semua standar sebesar $16,23 \%$ dari $25,50 \%$ pada saat survei dengan pencapaian target implementasi standar sebanyak 65,00\%. Analisis bivariat dengan uji korelasi chi-square menghasilkan nilai probabilitas sebesar o,85 (p o,05). Hasil ini menunjukkan tidak adanya hubungan antara perencanaan perbaikan strategis dengan hasil survei verifikasi 1. Artinya hasil uji membuktikan bahwa PPS tidak menentukan pelaksanaan standar akreditasi/hasil survei verifikasi terpenuhi secara menyeluruh.

Tabel 3. Distribusi frekuensi hasil survei verifikasi $1 \mathrm{RS}$ terakreditasi Paripurna SNARS edisi 1 periode 1 Januari 2018-31 Desember 2019

\begin{tabular}{lcc}
\hline Survei Verifikasi 1 & Frekuensi & Persen (\%) \\
\hline Belum terpenuhi & 3 & 37,50 \\
Terpenuhi & 5 & 62,50 \\
Total & 8 & 100,00 \\
\hline
\end{tabular}

Tabel 4. Persentase implementasi standar akreditasi hasil survei dan survei verifikasi 1 RS terakreditasi paripurna SNARS edisi 1 periode 1 Januari 2018-31 Desember 2019

\begin{tabular}{|c|c|c|c|c|c|c|}
\hline \multirow[b]{2}{*}{ Kelengkapan } & \multicolumn{2}{|c|}{ Survei } & \multicolumn{2}{|c|}{ Survei Verifikasi 1} & \multicolumn{2}{|c|}{ Hasil } \\
\hline & Terpenuhi & $\begin{array}{c}\text { Belum } \\
\text { terpenuhi }\end{array}$ & Terpenuhi & $\begin{array}{c}\text { Belum } \\
\text { terpenuhi }\end{array}$ & $\begin{array}{c}\text { Peningkatan } \\
\text { terpenuhi } \\
\text { setelah } \\
\text { verifikasi } 1\end{array}$ & $\begin{array}{c}\text { Pencapaian } \\
\text { setelah } \\
\text { survei } \\
\text { verifikasi 1 }\end{array}$ \\
\hline Standar Keselamatan Pasien (SKP) & 71,50 & 28,50 & 85,75 & 14,25 & 14,30 & 50,00 \\
\hline Akses Ke Rumah Sakit dan Kontinuitas Pelayanan (ARK) & 76,75 & 23,25 & 92,50 & 17,50 & 15,80 & 76,70 \\
\hline Hak Pasien dan Keluarga (HPK) & 82,75 & 17,25 & 93,87 & 6,13 & 11,10 & 64,50 \\
\hline Asesmen Pasien (AP) & 77,00 & 23,00 & 90,25 & 9,75 & 13,25 & 57,60 \\
\hline Pelayanan dan Asuhan Pasien (PAP) & 73,87 & 26,13 & 90,12 & 9,08 & 16,30 & 62,20 \\
\hline Pelayanan Anestesi dan Bedah (PAB) & 78,00 & 22,00 & 93,00 & 7,00 & 15,00 & 68,20 \\
\hline Pelayanan Kefarmasian dan Penggunaan Obat (PKPO) & 75,87 & 24,13 & 92,62 & 7,38 & 20,80 & 86,00 \\
\hline Manajemen Komunikasi dan Edukasi (MKE) & 67,87 & 32,13 & 85,25 & 14,75 & 17,70 & 55,00 \\
\hline Peningkatan Mutu dan Keselamatan Pasien (PMKP) & 68,75 & 31,25 & 91,75 & 8,25 & 23,00 & 73,60 \\
\hline Pencegahan dan Pengendalian Infeksi (PPI) & 76,00 & 24,00 & 92,63 & 7,00 & 17,00 & 71,00 \\
\hline Tata Kelola Rumah Sakit (TKRS) & 74,00 & 26,00 & 90,75 & 9,00 & 17,00 & 65,20 \\
\hline Manajemen Fasilitas dan Keselamatan (MFK) & 73,00 & 27,00 & 89,13 & 11,00 & 16,00 & 59,30 \\
\hline Kompetensi dan Kewenangan Staf (KKS) & 73,00 & 27,00 & 90,88 & 9,00 & 18,00 & 67,00 \\
\hline Manajemen Informasi dan Rekam Medis (MIRM) & 73,00 & 27,00 & 88,38 & 12,00 & 15,00 & 56,00 \\
\hline Program Nasional (PN) & 75,00 & 25,00 & 87,63 & 12,00 & 13,00 & 52,00 \\
\hline $\begin{array}{l}\text { Integrasi Pendidikan Kesehatan Dalam Pelayanan Rumah } \\
\text { Sakit (IPKP) }\end{array}$ & 76,00 & 24,00 & 96,60 & 3,00 & 21,00 & 87,50 \\
\hline
\end{tabular}

\section{Pembahasan}

PPS adalah rencana kerja tertulis yang dibuat oleh RS sebagai tindak lanjut hasil penilaian yang belum terpenuhi atau terpenuhi sebagian dari hasil survei. PPS diharapkan dapat menegakkan strategi/pendekatan yang akan diterapkan rumah sakit untuk menangani setiap temuan. Menjelaskan langkahlangkah spesifik yang digunakan untuk mencapai kepatuhan, menjelaskan langkah yang digunakan untuk berkomunikasi dan mengedukasi karyawan, menjelaskan metodologi untuk mencegah terjadinya kembali tindakan ketidakpatuhan dan mengevaluasi langkah evaluasi efektifitas dari rencana perbaikan².

Hasil survei verifikasi 1 menilai 16 standar yang belum terpenuhi yaitu, Sasaran Keselamatan Pasien (SKP), Akses ke Rumah Sakit dan Kontinuitas Pelayanan (ARK), Hak Pasien dan Keluarga (HPK), Asesmen Pasien (AP), Pelayanan dan Asuhan Pesien (PAP), Pelayanan Anestesi Bedah (PAB), Pelayanan Kefarmasian dan Penggunaan Obat (PKPO), Manajemen Komunikasi dan Edukasi (MKE), Peningkatan Mutu dan Keselamatan Pasien (PMKP), PPI, Tata Kelola Rumah Sakit
(TKRS), Manajemen Fasilitas dan Keselamatan (MFK), Kompetensi dan Kewenangan Staf (KKS), Manajemen Informasi dan Rekam Medis (MIRM), Program Nasional (PROGNAS) dan Integrasi Pendidikan Kesehatan Dalam Pelayanan Rumah Sakit (IPKP) ${ }^{2}$.

Hasil analisis membuktikan tidak ada hubungan PPS dengan hasil survei verifikasi 1 , artinya hasil uji membuktikan bahwa PPS tidak menentukan pelaksanaan standar akreditasi/hasil survei verifikasi terpenuhi secara menyeluruh. Walaupun hasil penelitian menunjukan tidak adanya hubungan tetapi PPS yang lengkap dapat meningkatkan implementasi standar akreditasi, karena keterbatasan pada penelitian ini yaitu responden tidak sesuai dengan perhitungan sampel, dan dari hasil penelitian yang didapatkan pada data PPS bahwa dari 5 sub variabel PPS, pada sub variabel metode perbaikan yang dibuat oleh RS dengan rerata 91,75 (SD 15,27) artinya RS memahami strategi dan metode yang akan dilaksanakan untuk perbaikan dan memenuhi standar berdasarkan rekomendasi surveyor sesuai Permenkes tahun 2020, tetapi pada sub variabel kesesuaian waktu implementasi maksimal satu bulan setelah survei rerata 
45,75 (SD 17,59), artinya metode perbaikan yang telah dibuat RS jelas target waktu implementasinya.

Pemenuhan standar akreditasi dari survei ke survei verifikasi ke-1 mencapai kenaikan sebesar $16,23 \%$ dari $25,50 \%$ pada saat survei, walaupun pencapaian target implementasi standar sebanyak 65,00\%. Jika dilihat selama satu tahun pemenuhan standar akreditasi dari survei ke survei verifikasi masih ada standar yang belum terpenuhi 9,20\%.

PPS yang diimplementasikan dievaluasi kemajuan dan dimonitoring pelaksanaannya secara berkesinambungan di tahun kedua, dan selanjutnya selama siklus tiga tahunan akreditasi $^{3}$. Sesuai tujuan survei verifikasi untuk mempertahankan dan/atau meningkatkan mutu pelayanan $\mathrm{RS}^{6}$, sejalan dengan penelitian ${ }^{8,16}$ bahwa dampak survei mutu pelayanan berulang secara periodik, maka mutu RS dari waktu ke waktu terjaga, walaupun kualitas pelayanan setelah survei akreditasi didapatkan ada penurunan tetapi kemudian akan meningkat kembali, artinya standar akreditasi terimplementasi dengan baik. Hal ini membuktikan bahwa proses akreditasi tidak diragukan lagi dapat mengintensifkan kegiatan yang berkontribusi pada peningkatan kualitas pelayanan RS7.

Pembinaan dan pengawasan terhadap kualitas pelayanan RS sesuai dengan status akreditasi membutuhkan komitmen dari pimpinan RS dengan mengikutsertakan pemerintah, pemerintah daerah, dan juga melibatkan organisasi profesi, asosiasi perumahsakitan, dan tokoh masyarakat ${ }^{9}$, agar RS dapat mempertahankan dan meningkatkan mutu pelayanan secara optimal $^{1}$.

\section{Kesimpulan}

Sebagian besar PPS yang dibuat rumah sakit masih belum lengkap terutama pada target waktu pemenuhan implementasi standar. Hasil survei verifikasi 1 ada kenaikan pencapaian implementasi standar dan hasil analisis menunjukkan tidak ada hubungannya antara PPS dengan hasil survei verifikasi 1, yang membuktikan bahwa PPS tidak menentukan pelaksanaan standar akreditasi. Sesuai amanat Permenkes nomor 12 tahun 2020 bahwa PPS harus dibuat sesuai dengan standar dan dilaksanakan dengan baik maka tujuan pemenuhan implementasi standar akreditasi paripurna akan tercapai sesuai dengan perencanaan. Diharapkan RS dapat melaksanakan 338 standar dan 1353 elemen penilaian standar akreditasi dengan baik dan tercapainya peningkatan mutu pelayanan RS secara maksimal.

PPS yang dibuat lengkap merupakan kompas yang dapat dijadikan petunjuk yang akan memudahkan RS dalam melaksanakan standar akreditasi. Selanjutnya untuk mempertahankan dan meningkatkan standar akreditasi yang telah dicapai perlu konsistensi implementasi dari PPS yang telah dibuat, dengan waktu yang telah ditentukan. Dilakukan evaluasi pelaksanaan standar akreditasi dengan monitoring secara berkala melalui survei verifikasi.
Perlu adanya optimalisasi pembuatan PPS dengan target waktu yang jelas termasuk waktu monitoring dan evaluasi pelaksanaan dari PPS yang telah dibuat. Penting untuk meningkatkan peran badan pengawas perumahsakitan dalam mengawasi pelaksanaan dan peningkatan mutu rumah sakit sehingga konsistensi upaya perbaikan dapat dilaksanakan secara berkesinambungan.

\section{Referensi}

1. Peraturan Menteri Kesehatan Republik Indonesia Nomor 12 Tahun 2020 tentang Akreditasi Rumah Sakit.

2. Komisi Akreditasi Rumah Sakit (KARS). Standar nasional akreditasi rumah sakit edisi 1.1. Jakarta: KARS; 2019.

3. Komisi Akreditasi Rumah Sakit (KARS). Standar nasional akreditasi rumah sakit edisi 1. Jakarta: KARS; 2018

4. Apriluana A, Dewi P, Natasha C, dkk. Hubungan antara usia, jenis kelamin, lama kerja, pengetahuan, sikap dan ketersediaan alat pelindung diri (APD) dengan perilaku penggunaan APD pada tenaga kesehatan. JPKMI 2016; 3(3):82-87. ISSN 2407-1625

5. Rusdianawati I, Usman S, Biiznillah GB, dkk. Evaluasi kepatuhan asesmen awal medis dan keperawatan.JHA 2021; 03(1): 27-33

6. Peraturan Menteri Kesehatan Republik Indonesia Nomor 34 Tahun 2017 tentang Akreditasi Rumah Sakit.

7. Petrovic MG, Vukovic M, Vranes JA. The impact of accreditation on health care quality in hospitals. Vojnosanit Pregl 2018; 75(8): 803808.

8. Devkaran S, O'Farrell PN, Ellahham S, dkk. Impact of repeated hospital accreditation surveys on quality and reliability, an 8-year interrupted time series analysis. BMJ open,2018: 9(2):024514.

9. Undang-Undang Nomor 44 Tahun 2009 tentang Rumah Sakit.

10. Komisi Akreditasi Rumah Sakit (KARS). (2020). Penilaian akreditasi rumah sakit. Diakses dari http://www. kars.or.id

11. Sugiyono. Metode penelitian kuantitatif kualitatuf dan R \& D. Bandung: Alfabeta; 2016

12. Dharma KK. Metodologi penelitian keperawatan panduan melaksanakan dan menerapkan hasil penelitian. Jakarta: CV Trans Info Media; 2011

13. Jha AK. Accreditation, Quality, and Making Hospital Care Better. JAMA. 2018;320(23): 2410-2411.

14. Avia I, Hariyati RTS. Impact of hospital accreditation on quality of care: A literature review. Enfermeria Clinica. 2019 Jan1:315-320. https://doi.org/10.1016/j.enfcli.2019.06.003

15. Mansour W, Boyd A, Walshe K. The development of hospital accreditation in low- and middle-income countries: a literature review. Health Policy Plan. 2020; 35(6):684-700

16. Bogh SB, Jensen AMS, Hollnagel E, dkk. Improvement in quality of hospital care during accreditation: A nationwide stepped-wedge study. International Journal for Quality in Health Care. 2016; 8 (6) Pages $715^{-72}$ 